\title{
A study on pre pregnancy body mass index and its effect on maternal and perinatal outcome
}

\author{
Bhuvaneshwari. K. ${ }^{1}$, Gayathri. N. ${ }^{2}$, Prema Priya. G. ${ }^{3}$, Dhingra S. ${ }^{4}$, Vimala D. ${ }^{5}$ \\ ${ }^{1}$ Dr. Bhuvaneshwari. K, Post Graduate Student, ${ }^{2}$ Dr. Gayathri. N., Assistant Professor, ${ }^{3}$ Dr. Prema Priya G, Assistant \\ Professor, ${ }^{4}$ Dr. Sakshi Dhingra, Post graduate, ${ }^{5}$ Dr. Vimala. D., Professor, all authors are affiliated with Department of \\ Obstetrics and Gynaecology, Vinayaka Missions Kirupanandavariyar Medical College, VMRF(DU), Salem, Tamilnadu, \\ India.
}

Corresponding Author: Dr. Prema Priya. G., Assistant Professor, Department of Obstetrics and Gynaecology, Vinayaka Missions Kirupanandavariyar Medical College, VMRF(DU), Salem. Tamilnadu. Mail: dr.premapriya.r@gmail.com

\begin{abstract}
Background: Obesity is now a major public health problem. It has detrimental effect to mother and fetus. Maternal malnutrition also has a negative impact. Materials and Methods: 500 women with singleton pregnancy and spontaneous conception, who attended antenatal OPD in our tertiary hospital, were included in this study after informed consent. Those with known pre-pregnancy weight, pre pregnancy BMI was calculated using the formula BMI= weight in kilograms/ height in metre square. They were followed up until delivery and their maternal and perinatal outcomes such as anaemia, gestational hypertension, gestational diabetes, preterm labour, past dates, intrauterine growth restriction, low birth weight and neonatal intensive care admission were studied. Results: The mean age of the woman in this study was $24.3 \pm 2.4$ years. Of these, $14 \%(n=70)$ of women were underweight. $43 \%(n=215)$ of women were of normal BMI. $34 \%$ $(n=170)$ of women were overweight. $9 \%(n=45)$ of women were obese. Maternal complications such as anaemia, preterm labour and intrauterine growth restriction were significantly common in underweight woman. Gestational diabetes and gestational hypertension were more in obese woman. Low birth weight babies were more in underweight woman. Conclusion: Pre pregnancy counselling should be given to woman of childbearing age to maintain normal BMI to prevent maternal and neonatal complications.
\end{abstract}

Keywords: Body mass index, Maternal outcome, Fetal outcome, Obese

\section{Introduction}

There has been a dramatic increase in the prevalence of overweight and obesity worldwide. Obesity is now a global epidemic. Maternal obesity has become a major challenge to the treating obstetricians. Obesity is the accumulation of excess body fat. Obesity can be diagnosed by various markers such as body mass index (BMI), waist circumference, waist to hip circumference, skin fold thickness, serum cholesterol, triglycerides level, etc [1].

Maternal obesity has a negative impact for both mother and the fetus. Obesity leads to rise in infertility and assisted reproductive treatments. The obese mother is at the risk of abortion, preeclampsia, gestational diabetes, past-dates, increased caesarean delivery, postpartum haemorrhage, puerperal infection and thromboembolism

Manuscript received: $25^{\text {th }}$ August 2019

Reviewed: $4^{\text {th }}$ September 2019

Author Corrected: $10^{\text {th }}$ September 2019

Accepted for Publication: $16^{\text {th }}$ September 2019
[2-5]. The fetus is at the risk of increased congenital anomaly, macrosomia, stillbirth, perinatal morbidity and mortality. Obesity is a known risk factor for many health problems in future such as diabetes, hypertension, coronary artery disease, stroke, etc., The child is at the risk of future obesity, diabetes and metabolic syndrome.

Maternal malnutrition also has a detrimental effect both to the mother and the fetus. Underweight BMI women are at the risk of anaemia, intrauterine growth retardation, small for gestation age babies and intensive care unit admissions. Thus, the nutritional status of the woman plays a key role in determining the perinatal outcome. Body mass index (BMI) is defined as the body mass in kilograms divided by the square of body height in metres. It is expressed as $\mathrm{kg} / \mathrm{m}^{2}$. According to the BMI, people are classified as underweight $<18.5 \mathrm{~kg} / \mathrm{m}^{2}$, normal weight 18.6 to $24.9 \mathrm{~kg} / \mathrm{m}^{2}$, overweight 25.0 to 
$25.9 \mathrm{~kg} / \mathrm{m}^{2}$ and obese $>30 \mathrm{~kg} / \mathrm{m}^{2}$. The aim of the present study was to find the effect of pre pregnancy BMI on maternal and perinatal outcome.

\section{Materials and Methods}

Study design: Prospective observational study.

Study period: One year from January 2018 to February 2019 in a tertiary hospital in Salem district of Tamil Nadu.

Study population: 500 women with singleton pregnancy with spontaneous conception who attended antenatal OPD in first trimester.

Exclusion criteria: Multiple pregnancy, assisted reproductive technique conception, past or present medical disorders and those not willing for follow up.

\section{Original Research Article}

Methodology: 500 women who attended antenatal OPD in our tertiary hospital were included in this study after informed consent.

Those with known pre-pregnancy weight, pre pregnancy BMI was calculated using the formula $\mathrm{BMI}=$ weight in kilograms/ height in metre square. $\mathrm{T}$

hey were followed up until delivery and their maternal and perinatal outcomes such as anaemia, gestational hypertension, gestational diabetes, preterm labour, pastdates, intrauterine growth restriction, low birth weight and neonatal intensive care admission were studied.

Statistical analysis was done using SPSS 21. The $\mathrm{p}$ value less than 0.005 considered as statistically significant.

\section{Results}

500 women were included in this study. The mean age of the participants in this study was $24.3 \pm 2.4$ years. Table 1 describes the distribution of age in study participants. $55 \%(n=275)$ of women were in the age group of 26 to 30 years. $28 \%(n=140)$ of women were in the age group of 21 to 25 years. $8 \%(n=40)$ of women were in the age group of less than 20 years. $9 \%(n=45)$ of women were in the age group of more than 30 years.

Table-1: Age distribution

\begin{tabular}{|c|c|}
\hline Age group (Years) & $\mathbf{N = 5 0 0 , \mathbf { n } ( \% )}$ \\
\hline$<20$ & $40(8)$ \\
\hline $21-25$ & $140(28)$ \\
\hline $26-30$ & $275(55)$ \\
\hline$>30$ & $45(9)$ \\
\hline
\end{tabular}

Table 2 describes the distribution of gravida in the study participants. 53\% $(\mathrm{n}=265)$ of women were primigravida. $36 \%$ $(n=180)$ of women were second gravida. $11 \%(n=55)$ of women were third gravida.

Table-2: Distribution of gravida

\begin{tabular}{|c|c|}
\hline Gravida & $\mathbf{N}=\mathbf{5 0 0 , \mathbf { n } ( \% )}$ \\
\hline 1 & $265(53)$ \\
\hline 2 & $180(36)$ \\
\hline 3 & $55(11)$ \\
\hline
\end{tabular}

Table 3 describes the distribution of maternal BMI in the study participants. $14 \%(n=70)$ of women were underweight. $43 \%(n=215)$ of women were of normal BMI. $34 \%(n=170)$ of women were overweight. $9 \%(n=45)$ of women were obese.

Table-3: BMI distribution

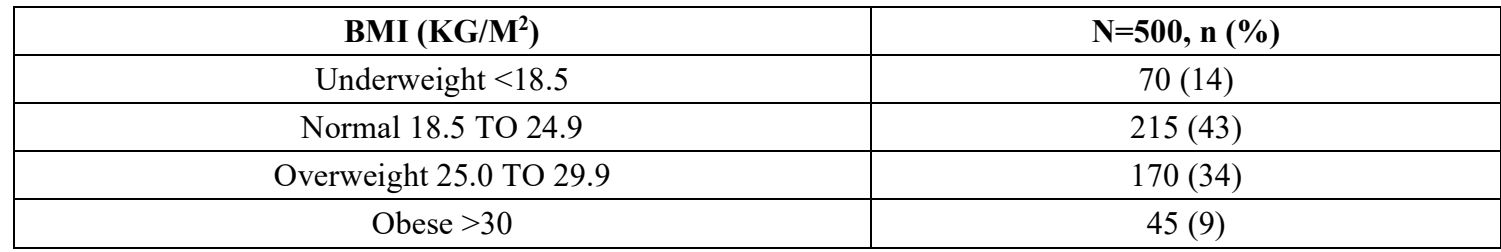




\section{Original Research Article}

Table 4 describes the maternal complications. Anaemia was more common $50 \%$ in underweight women followed by obese $27 \%$, normal BMI women $23 \%$ and overweight $11 \%$. $(\mathrm{p}=0.088)$ statistically significant. Gestational hypertension was found in $33 \%$ of obese women followed by overweight $9 \%$ and normal BMI women $8 \%$. Gestational diabetes was found in $13 \%$ of obese women followed by overweight women $7 \%$ and normal BMI women $3 \%$. Preterm birth was more common in underweight women $28.5 \%$ followed by obese $11 \%$, overweight $6 \%$ and normal weight $2.3 \%$. $(\mathrm{p}=0.017)$ statistically significant. Past dates were more in obese women $22 \%$ followed by overweight women $3.5 \%$. Intrauterine growth restriction was significantly associated with underweight women $20 \%(\mathrm{p}=0.004)$.

Table-4: Maternal complications

\begin{tabular}{|c|c|c|c|c|c|}
\hline Complications & $\begin{array}{l}\text { Underweight } \\
\mathrm{N}=70, \mathrm{n}(\%)\end{array}$ & $\begin{array}{c}\text { Normal } \\
\mathrm{N}=\mathbf{2 1 5}, \mathrm{n}(\%)\end{array}$ & $\begin{array}{c}\text { Overweight } \\
\text { N= 170, n (\%) }\end{array}$ & $\begin{array}{c}\text { Obese } \\
\mathrm{N}=\mathbf{4 5}, \mathrm{n}(\%)\end{array}$ & P Value \\
\hline Anaemia & $35(50)$ & $50(23)$ & $20(11)$ & $12(27)$ & 0.088 \\
\hline Gestational hypertension & NIL & $18(8)$ & $21(9)$ & $15(33)$ & 0.36 \\
\hline Gestational diabetes & NIL & $6(3)$ & $12(7)$ & $6(13)$ & 0.6 \\
\hline Preterm & $20(28.5)$ & $5(2.3)$ & $10(6)$ & $5(11)$ & 0.017 \\
\hline Pastdates & NIL & NIL & $6(3.5)$ & $10(22)$ & 0.5 \\
\hline IUGR & $14(20)$ & NIL & $5(3)$ & $2(4)$ & 0.004 \\
\hline
\end{tabular}

The rate of caesarean deliveries was more in obese women followed by underweight, overweight and normal BMI women contributing $55.6 \%, 37 \%, 31.2 \%$ and $23.2 \%$ respectively. Instrumental deliveries were also more in obese women contributing $11.1 \%$. The incidence of PPH was more in obese and overweight women accounting to $22 \%$ and $6 \%$ respectively. There was no wound sepsis in the study population.

Low birth weight $<2.5$ kilogram babies were more common in underweight women $21 \%$ ( $\mathrm{n}=14)$. Macrosomia babies $>$ 3.5 kilogram was seen in obese women $22 \%(\mathrm{n}=10)$ followed by overweight women $5.2 \%(\mathrm{n}=9)$. Neonatal intensive care admission was required in $33 \%$ of obese women followed by $21 \%$ of underweight women. The $\mathrm{p}$ value $=0.024$ statistically significant. The low apgar scores less than 7 was found more in obese women contributing $18 \%(\mathrm{n}=8)$ followed by underweight women $7 \%(\mathrm{n}=5)$ and overweight women $5 \%(\mathrm{n}=10)$.

\section{Discussion}

Maternal nutrition is directly linked to the nutrition of the baby. Both malnutrition and obesity has detrimental effect both to the mother and fetus. A malnourished mother gives birth to undernourished child, whereas overnutrition mother gives birth to obese child.

In the present study, mean age of the study population was $24.3 \pm 2.4$ years. Anaemia was significantly common in underweight group woman $(\mathrm{p}=0.088)$. Gestational hypertension and gestational diabetes was more common in obese woman. However. it was not statistically significant. In studies done by Uebe $\mathrm{K}$ et al, Abenhaim HA, John J, Athukorala C, Murakmi M et al, there was significant association of gestational diabetes and gestational hypertension in obese woman [6-9].

In studies done by Park JH, Tsai LH, Bhattacharya S et al, overweight woman, obese and morbidly obese woman were at increased risk of gestational hypertension, preeclampsia, gestational diabetes, preterm labour, macrosomia, induction of labour and caesarean delivery [10-13]. Tharihalli and Thathagari also reported significant increase in PIH with increase in maternal obesity [14]. Frederick et al reported that for every $1 \mathrm{~kg} / \mathrm{m} 2$ rise in pre-pregnancy BMI there occurs $8 \%$ increase in preeclampsia [15].

Caesarean delivery was more $55 \%$ in obese woman in this study. Cedergren, Denison, Doherty and Callaway et al also reported the same, that overweight and obese woman are at increased risk of caesarean delivery [1619]. This is because of the fact that as maternal BMI increases, baby birth weight increases and so the caesarean delivery.

Denison et al reported that higher maternal BMI was associated with decreased likelihood of spontaneous onset of labour, increased likelihood of postdates and its complications [17]. Cedergren et al concluded that obese women may benefit from low weight gain during pregnancy [16]. In the present study intrauterine growth restriction, preterm deliveries, neonatal intensive care 
Original Research Article

admission were significantly higher in underweight woman followed by obese and overweight women. Their $\mathrm{p}$ values were statistically significant. In studies done by Murakmi M, Abenhaim HA and Sahu MT et al there was significant association of underweight women with low birthweight, small for gestation age and intrauterine growth restriction infants $[9,10,20]$. Hospitalisation of the infants was higher in the underweight woman population.

In studies done by Abenhaim HA, Athukorala $\mathrm{C}$ et al concluded that increased pre-pregnancy BMI category such as overweight and obese woman were associated with increased adverse pregnancy outcomes [7, 9]. Tsai $\mathrm{IH}$ et al concluded that an appropriate maternal BMI $(18.5-24 \mathrm{~kg} / \mathrm{m} 2)$ at conception with appropriate weight gain (10-14 kg) during pregnancy has good maternal and fetal outcome.

Thus, it was clearly evident from this study that both undernutrition and obese maternal BMI had adverse maternal and fetal outcomes. The results of this study emphasize the importance of good nutritional status of the woman before and during pregnancy for achieving the healthy pregnancy outcome. Maintaining adequate nutrition and normal BMI before pregnancy reduces both maternal and neonatal morbidities and mortalities in future.

Limitation: This type of study should be conducted in large population to obtain significant results.

\section{Conclusion}

Body mass index (BMI) plays a major role in fertility potential, pregnancy and delivery. Both underweight and overweight, obese woman are at risk of maternal and fetal complications.

Hence pre pregnancy counselling should be given to women to maintain normal BMI. Lifestyle modification is advised in obese and overweight woman. Thus, appropriate pre-pregnancy BMI and appropriate weight gain during pregnancy has overall good impact on maternal and neonatal outcome.

\section{What the study adds to the existing knowledge?}

that both underweight and overweight, obese BMI has negative impact to the mother and fetus. Hence pre pregnancy counselling should be given to woman of childbearing age to maintain normal BMI to achieve health pregnancy and childbirth.

\section{Author's contribution}

Dr. Bhuvaneswari. K and Dr. Gayathri. $\mathbf{N}$ contributed to study design and concept.

Dr. Prema Priya. G drafted manuscript. Dr. Sakshi Dhingra contributed data analysis. Dr. Vimala. D supported the study.

\section{Funding: Nil, Conflict of interest: Nil Permission from IRB: Yes}

\section{References}

1. Choudhary J, Singh S, Tiwari K. Study of BMI in pregnancy and its correlation with maternal and perinatal outcome. Int $\mathrm{J}$ Reprod Contracept Obstet Gynecol. 2018;7(6):2472-2479. doi: http://dx.doi.org/ 10. $18203 / 2320-1770 . i j r \operatorname{cog} 20182371$

2. Riz AM, Laraia B. The implications of maternal overweight and obesity on the course of pregnancy and birth outcomes. Matern Child Health J. 2006;10(5): S153-S156. doi: 10.1007/s10995-006-0115-x

3. Andreasen KR, Andersen ML, Schantz AL. Obesity and pregnancy. Acta Obstet Gynecol Scand. 2004;83 (11): 1022-1029.doi:https:// doi.org/ 10.1111/j.00016349. 2004. 00624.x

4. Guelinckx I, Devlieger R, Beckers K, Vansant G. Maternal obesity: pregnancy complications, gestational weight gain and nutrition. Obes Rev. 2008;9(2):140150. doi:https:// doi.org/ 10.1111/j.1467-789X.2007. 00464.x

5. Heslehurst N, Simpson H, Ells LJ, Rankin J, Wilkinson J, Lang R, et al. The impact of maternal BMI status on pregnancy outcomes with immediate shortterm obstetric resource implications: a metaanalysis. Obes Rev. 2008; 9(6): 635-683. doi: 10.1111/j.1467789X. 2008.00511. x.

6. Uebel K, Pusch K, Gedrich K, Schneider KM, Hauner H, Bader BL. Effect of maternal obesity with and without gestational diabetes on offspring subcutaneous and preperitoneal adipose tissue development from birth up to year-1. BMC Pregnancy and Childbirth. 2014; 14:138. doi: 10.1186/1471-239314-138

7. Abenhaim HA, Kinch RA, Morin L, Benjamin A, Usher R. Effect of prepregnancy body mass index categories on obstetrical and neonatal outcomes. Arch Gynecol Obstet. 2007;275(1):39-43. doi: 10.1007/ s00404-006-0219-y 


\section{Original Research Article}

8. John J, Mahendran M. Maternal and fetal outcomes of obese pregnant women: a prospective cohort study. Int J Reprod Contracept Obstet Gynecol. 2017;6(2): 725-729. doi: http://dx.doi.org/10.18203/2320-1770. ijrcog 20170413

9. Athukorala C, Rumbold AR, Willson KJ, Caroline AC. The risk of adverse pregnancy outcomes in women who are overweight or obese. BMC Pregnancy and Childbirth. 2010; 10:56. doi: 10.1186/ 1471-2393$10-56$

10. Murakmi M, Ohmichi M, Takahashi T, Shibata A, Fukao A, Morisaki N, Kurachi H: Prepregnancy body mass index as an important predictor of perinatal outcomes in Japanese. Arch Gynecol Obstet. 2005;271 (4): 311-315. doi: https://doi.org/10.1007/s00404-0040629-7

11. Park JH, Lee BE, Park HS, Ha EH, Lee SW, Kim YJ. Association between pre-pregnancy body mass index and socioeconomic status and impact on pregnancy outcomes in Korea. J Obstet Gynaecol Res. 2011; 37(2): 138-145. doi: 10.1111/j.1447-0756.2010. 01332. x.

12. Tsai IH, Chen CP, Sun FJ, Wu CH, Yeh SL. Associations of the pre-pregnancy body mass index and gestational weight gain with pregnancy outcomes in Taiwanese women. Asia Pac J Clin Nutr. 2012; 21(1): 82-87. doi: 10.6133/apjen.2012.21.1.11

13. Bhattacharya S, Campbell DM, Liston WA, Bhattacharya S. Effect of body mass index on pregnancy outcomes in nulliparous women delivering singleton babies. BMC Public Health 2007; 7:168. doi: 10.1186/1471-2458-7-168.
14. Tharihalli C, Thathagari V. Study of correlation between maternal body mass index with maternal and perinatal outcome. Int $\mathrm{J}$ Reprod Contracept Obstet Gynecol. 2017;6(1):164-167. doi: http://dx.doi.org/ 10. 18203/ 2320-1770. ijrcog20164650

15. Frederick IO, Rudra CB, Miller RS, Foster JC, Williams MA. Adult weight change, weight cycling, and prepregnancy obesity in relation to risk of preeclampsia. Epidemiol. 2006;17(4):428-434. doi: 10. 1097/01.ede. 0000221028. 33245.0b,

16. Cedergren M. Effects of gestational weight gain and body mass index on obstetric outcome in Sweden. Int J Gynaecol Obstet. 2006;93(3):269-274. doi: https://doi. org/ 10. 1016/j.ijgo.2006.03.002

17. Denison F, Price J, Graham C, Wild S, Liston W. Maternal obesity, length of gestation, risk of postdates pregnancy and spontaneous onset of labour at term. BJOG. 2008;115(6): 720-725. doi: 10.1111/j.147105282008. 01694.xx

18. Doherty DA, Magann EF, Francis J, Morrison JC, Newnham JP. Prepregnancy body mass index and pregnancy outcomes. Int J Gynae Obst. 2006;95(3):242247. doi: 10.1016/j.ijgo.2006.06.021.

19. Callaway LK, Prins JB, Chang AM, McIntyre HD: The prevalence and impact of overweight and obesity in an Australian obstetric population. Med J Australia. 2006;184(2):56-59. doi: https://doi.org/10.5694/j.13265377. 2006. tb00115.x

20. Sahu MT, Agarwal A, Das V, Pandey A. Impact of maternal body mass index on obstetric outcome. J Obstet Gynaecol Res. 2007;33(5):655-659. doi: https:// doi. org/10.1111/j.1447-o756.2007.00646.x

\section{How to cite this article?}

Bhuvaneshwari. K, Gayathri. N, Prema Priya. G, Dhingra S, Vimala D.A study on pre pregnancy body mass index and its effect on maternal and perinatal outcome. Obs Rev: J obstet Gynecol 2019;5(4):181-185.doi:10.17511/joog.2019.i04.01. 